\title{
EKSTRAKSI PIGMEN ANTOSIANIN DARI KULIT RAMBUTAN (Nephelium lappaceum) DENGAN PELARUT ETANOL
}

\author{
Laura Olivia Siahaan, Elvi Rasida Florentina Hutapea, Rondang Tambun \\ Departemen Teknik Kimia, Fakultas Teknik Universitas Sumatera Utara \\ Jl. Almamater Kampus USU Medan, 20155 Indonesia \\ Email : laurasiahaan91@yahoo.com
}

\begin{abstract}
Abstrak
Rambutan (Nephelium lappaceum Linn) merupakan sejenis buah-buahan tropika yang berasal dari Malaysia dan Indonesia. Kulitnya yang berwarna merah masih belum dimanfaatkan secara maksimal. Adanya warna merah pada kulit rambutan diduga terdapat pigmen antosianin yang dapat digunakan sebagai pewarna alami. Penelitian ini bertujuan untuk mengetahui kondisi terbaik yang dicapai dalam perolehan pigmen antosianin dari kulit rambutan dengan menggunakan pelarut etanol. Penelitian ini memvariasikan berbagai kondisi operasi yaitu ukuran partikel dari kulit rambutan, temperatur dan waktu ekstraksi. Analisis antosianin dilakukan dengan menggunakan spektrofotometer UV-Vis untuk mengukur panjang gelombang dan nilai absorbansinya. Ukuran kulit rambutan yang terbaik adalah kulit rambutan yang diblender dan hasil terbaik diperoleh pada temperatur $70{ }^{\circ} \mathrm{C}$ dan waktu ekstraksi selama 8 jam. Kondisi ini memberikan nilai intensitas warna dengan absorbansi 1,0086, konsentrasi 120,1601 mg/L dan rendemen sebesar 0,6008 \%.
\end{abstract}

Kata kunci: rambutan, kulit rambutan, antosianin

\begin{abstract}
Rambutan fruit (Nephelium lappaceum Linn) is a kind of tropical fruits which come from Malaysia and Indonesia. Their red coloured rinds have not used yet effectively and that coloured may be due to anthocyanin that can be used for natural colours. The purpose of this research is to know the optimal condition of the extraction anthocyanin, they are particle size of rambutan rinds, temperature and extraction time. Analysis of the anthocyanin use spectrophotometer $U V$-Vis to detect the wavelength and the absorbance of the anthocyanin. The best conditions are rambutan rind milled by blender and extraction time for 8 hours at $70^{\circ}$ of temperature. These conditions give the highest color intensity having 1,0086 of maximal absorbancy, $120,1601 \mathrm{mg} / \mathrm{mL}$ of anthocyanin concentration and $0,6008 \%$ of rendement.
\end{abstract}

Keywords: rambutan, rambutan rind, anthocyanin

\section{Pendahuluan}

Indonesia adalah salah satu negara tropis yang dikenal memiliki beranekaragam tanaman buah-buahan dan sayur-sayuran. Diantara berbagai buah-buahan tersebut, buah rambutan merupakan buah musiman yang banyak digemari karena kandungan vitamin $\mathrm{C}$ nya. Kulitnya yang berwarna merah masih belum dimanfaatkan, adanya warna merah tua diduga terdapat pigmen antosianin yang dapat digunakan sebagai pewarna alami [10]. Penggunaan zat warna alam untuk makanan dan minuman tidak memberikan kerugian bagi kesehatan, tidak seperti zat warna sintetik yang menimbulkan dampak negatif. Diantara zat warna sintetik yang sangat berbahaya untuk kesehatan sehingga penggunaannya dilarang adalah zat warna merah rhodamin B. Salah satunya yaitu rhodamin B (merah) yang sering digunakan pada makanan ringan dan saos. Penggunaan pewarna tekstil ini berbahaya jika dikonsumsi dalam jangka panjang yaitu dapat menimbulkan kanker dan kerusakan hati serta ginjal [3].

Pada penelitian ini, kulit buah rambutan merah akan diteliti sebagai sumber antosianin. Yang menjadi permasalahan dalam penelitian ini adalah bagaimana pengaruh ukuran kulit rambutan, temperatur dan waktu ekstraksi dalam menghasilkan pigmen antosianin dari kulit buah rambutan dengan menggunakan pelarut etanol.

\section{Teori}

Antosianin adalah metabolit sekunder dari famili flavonoid, dalam jumlah besar ditemukan dalam buah-buahan dan sayursayuran. Antosianin dapat memberikan warna merah, violet, ungu dan biru pada daun, bunga, buah dan sayur. Antosianin adalah suatu flavon yang larut dalam air, secara luas terbagi dalam polifenol tumbuhan dinamakan 
flavonoid. Flavonoid mengandung dua cincin benzen yang dihubungkan oleh tiga atom karbon. Flavonol, flavan-3-ol, flavon, flavanon dan flavanonol adalah kelas tambahan flavonoid yang berbeda dalam oksidasi dari antosianin [15].

Antosianin kurang stabil dalam larutan netral atau basa karena itu antosianin harus diekstraksi dari tumbuhan dengan pelarut yang mengandung asam hidroklorida dan larutannya harus disimpan di tempat yang gelap serta sebaiknya didinginkan [17]. Antosianin larut dalam pelarut polar seperti metanol, aseton atau kloroform, air, yang diasamkan dengan asam klorida atau asam format. Antosianin dilihat dari penampakan berwarna merah, merah senduduk, biru dan ungu, mempunyai panjang gelombang maksimum 465 - $560 \mathrm{~nm}$ [11].

\section{Metodologi Penelitian}

Bahan baku utama yang digunakan adalah kulit rambutan. Bahan baku penunjangnya adalah pelarut organik yaitu etanol yang diasamkan dengan asam klorida $(\mathrm{HCl})$. Bahan analisis yang digunakan adalah larutan buffer potassium klorida dan larutan buffer sodium asetat.

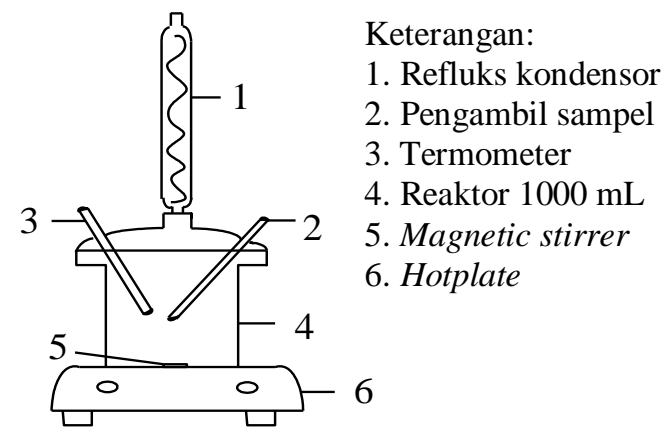

\section{Gambar 1. Rangkaian Peralatan}

Pada gambar 1 dapat dilihat rangkaian peralatan yang digunakan dalam penelitian ini yang meliputi ekstraktor sebagai peralatan utama dan beberapa peralatan penunjang.

Penelitian ini dilakukan untuk mendapatkan kondisi optimum ekstraksi antosianin dari kulit rambutan dengan memvariasikan beberapa perlakuan dan kondisi operasi. Pelarut yang digunakan adalah etanol. Ukuran kulit rambutan yaitu 50, 70, 100 dan 140 mesh, kulit rambutan yang dipotong kecilkecil dengan ukuran $0,5 \times 0,5 \mathrm{~cm}$ dan kulit rambutan yang diblender. Untuk temperatur reaksinya adalah: $\mathrm{T}_{1}=30{ }^{\circ} \mathrm{C}, \mathrm{T}_{2}=40{ }^{\circ} \mathrm{C}, \mathrm{T}_{3}=$ $50{ }^{0} \mathrm{C}, \mathrm{T}_{4}=60{ }^{0} \mathrm{C}$ dan $\mathrm{T}_{5}=70{ }^{0} \mathrm{C}$, sedangkan waktu reaksi yang diperlukan adalah selama: $\mathrm{t}_{1}$ $=2$ jam, $\mathrm{t}_{2}=4 \mathrm{jam}, \mathrm{t}_{3}=6$ jam dan $\mathrm{t}_{4}=8 \mathrm{jam}$.
Penelitian pendahuluan yang dilakukan adalah pembuatan bubuk kulit rambutan dan persiapan larutan untuk diekstraksi. Kulit rambutan dicuci dengan air, kemudian dipotong tipis-tipis. Kulit rambutan yang telah bersih dikeringkan dengan dijemur sinar matahari selama 3 hari hingga mencapai kadar air 9\%. Setelah kering, irisan kulit rambutan ini digiling dengan ball mill kemudian diayak 50, 70, 100 dan 140 mesh. Bubuk kulit rambutan yang dihasilkan kemudian dikemas dengan menggunakan plastik untuk menghindari penyerapan uap air di udara serta untuk menghindari dari bahan kontaminan lainnya. Perlakuan lainnya yaitu dipotong kecil-kecil dengan ukuran 0,5 x 0,5 cm dan diblender.

Kulit rambutan yang akan diekstrak ditimbang sebanyak 80 gram, lalu dimasukkan ke dalam labu leher tiga $1000 \mathrm{~mL}$, kemudian ditambahkan pelarut etanol dengan perbandingan 1:10. Pelarut tersebut diasamkan dengan $\mathrm{HCl} 1 \%$. Campuran ini diekstraksi sampai interval waktu yang ditentukan. Ekstrak yang diperoleh disaring dengan menggunakan kertas saring Whatman No.1. Hasil penyaringan berupa ampas dan pelarut yang mengandung antosianin. Ampas kulit rambutan dibuang dan cairan yang diperoleh kemudian dimasukkan ke dalam oven untuk menghilangkan pelarutnya. Dari proses tersebut diperoleh pigmen antosianin yang bebas pelarut. Antosianin yang dihasilkan ini kemudian disimpan pada suhu rendah sebelum dianalisis dengan menggunakan spektrofotometer UVVis. Analisis yang dilakukan adalah analisis $\mathrm{pH}$, intensitas warna, konsentrasi antosianin dan rendemen antosianin.

\section{Hasil dan Pembahasan Penelitian Pendahuluan}

Penelitian pendahuluan dilakukan untuk menentukan ukuran optimum kulit rambutan dalam ekstraksi antosianin dari kulit rambutan. Variasi ukuran kulit rambutan adalah dengan mengggunakan variasi ayakan 50, 70, 100 dan 140 mesh. Sebelum diekstraksi, terlebih dahulu dilakukan persiapan bahan baku. Kulit rambutan yang sudah dicuci dipotong kecilkecil lalu dikeringkan dalam oven dan juga di bawah sinar matahari. Setelah itu dimasukkan ke dalam ball mill untuk dihancurkan dan menjadi bubuk, kemudian diayak dengan variasi ukuran ayakan 50, 70, 100 dan 140 mesh. Namun, pre-treatment ini tidak menghasilkan larutan yang mengandung antosianin. Adapun indikator yang menyatakan bahwa tidak diperoleh antosianin dilihat dari warna larutan yang kecoklatan, memiliki $\mathrm{pH}$ 
4,5-7 dan panjang gelombangnya tidak berada direntang panjang gelombang antosianin yaitu 465-560 nm [11]. Hal ini diduga karena pemanasan dan paparan sinar matahari. Cahaya dapat menyebabkan berkurangnya intensitas suatu zat warna. Suhu yang tinggi akan menyebabkan degradasi antosianin. Pada penelitian ini kestabilan intensitas warna antosianin dari ekstrak kulit rambutan semakin berkurang setelah dilakukan proses pemanasan. Degradasi antosianin meningkat pada suhu tinggi dan terhadap paparan cahaya [2]. Laju kerusakan degradasi termal menyebabkan hilangnya warna pada antosianin yang akhirnya terjadi pencoklatan [9]. Hasil ekstraksi menggunakan ukuran ayakan adalah larutan berwarna coklat. Hal ini dikarenakan pengeringan mempunyai kekurangan yaitu dapat merusak sifat dan karakteristik dari bahan yang dikeringkan misalnya bentuknya, sifat- sifat fisik kimianya dan penurunan mutunya [6].

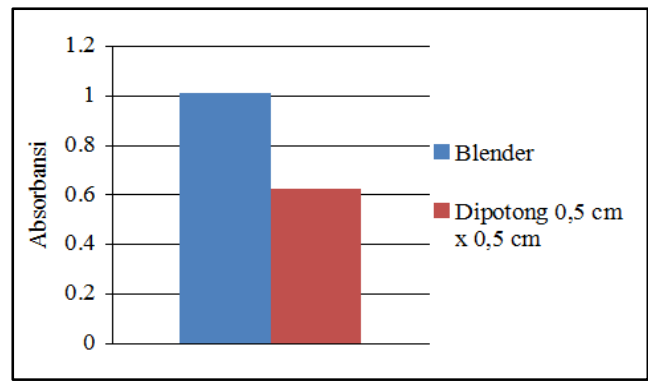

Gambar 2. Perbandingan Nilai Absorbansi dari Kulit Rambutan yang Dipotong Kecilkecil dan Kulit Rambutan yang Diblender

Pada gambar 2 terlihat bahwa nilai absorbansi dari kulit rambutan yang diblender adalah 1,0086 dengan perolehan rendemen sebesar $0,1544 \%$. Sedangkan kulit rambutan yang dipotong $0,5 \mathrm{~cm} \times 0,5 \mathrm{~cm}$ memiliki absorbansi 0,625 dan rendemen yang dihasilkan adalah 0,073\%. Kulit rambutan yang diblender menghasilkan rendemen yang lebih tinggi dibandingkan kulit rambutan yang dipotong $0,5 \mathrm{~cm} \times 0,5 \mathrm{~cm}$. Semakin kecil ukuran sampel semakin besar luas kontak area permukaan dengan pelarut sehingga menghasilkan antosianin yang terbaik [16]. Memperkecil ukuran padatan adalah suatu cara agar lintasan kapiler yang harus dilewati (secara difusi) menjadi lebih pendek dan tahanan akan berkurang [12].

\section{Pengujian Antosianin}

Pada penelitian ini dilakukan uji secara fisik untuk memastikan bahwa filtrat hasil ekstraksi kulit rambutan benar mengandung antosianin. Pengukuran $\mathrm{pH}$ terhadap filtrat yang mengandung antosianin ditunjukkan pada gambar 3 .

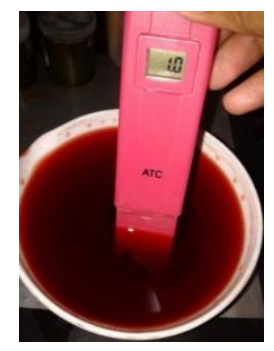

\section{Gambar 3. Pengukuran pH terhadap} Filtrat yang Mengandung Antosianin

Pada filtrat dimungkinkan mengandung pigmen antosianin karena dilakukan uji kualitatif sederhana dengan menggunakan asam klorida $(\mathrm{HCl})$ dan natrium hidroksida $(\mathrm{NaOH})$. Perlakuannya ialah dilakukan penambahan $\mathrm{NaOH}$ terhadap filtrat maka kemudian larutan filtrat berubah menjadi coklat kekuningan. Selanjutnya dilakukan penambahan $\mathrm{HCl}$ pada filtrat, larutan tersebut kemudian berubah warna menjadi warna merah lagi. Pada ekstrak kulit buah rambutan dibuktikan mengandung pigmen antosianin dengan perlakuan penambahan basa (alkali), larutan filtrat berubah menjadi coklat kekuningan kemudian dengan penambahaan asam larutan filtrat menjadi warna merah lagi [11].

Selanjutnya, filtrat hasil ekstraksi kulit rambutan kemudian dianalisa dengan menggunakan spektrofotometer UV-Vis untuk memastikan keberadaan pigmen tersebut dalam filtrat yang dihasilkan. Hasil spektrofotometer UV-Vis yaitu berupa panjang gelombang antosianin ditunjukkan pada Gambar 4.

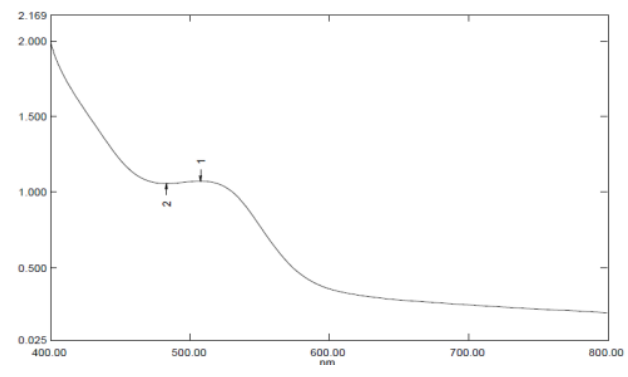

Gambar 4.Panjang Gelombang Antosianin 
Pada pengukuran menggunakan spektrofotometer diperoleh panjang gelombang dari kulit rambutan yang diblender $514,5 \mathrm{~nm}$. Antosianin memiliki range daerah spektrum tampak pada 465-560 nm [11]. Pada kondisi asam, antosianin berada pada $\mathrm{pH} 1-3$ [4].

\section{Intensitas Warna}

Intensitas warna menunjukkan kepekatan warna merah dalam kulit rambutan.

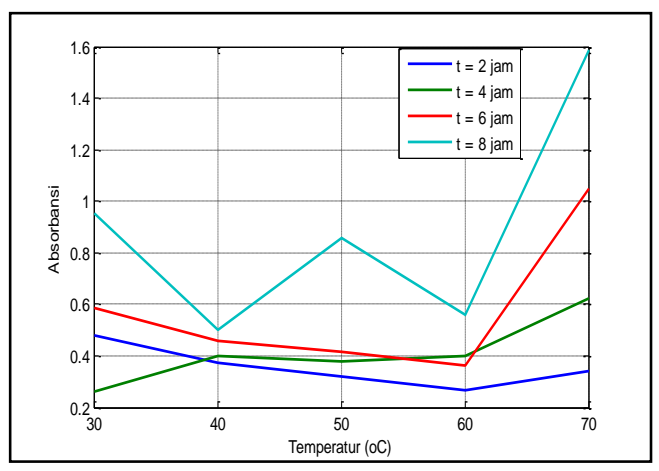

Gambar 5. Pengaruh Temperatur terhadap Absorbansi Maksimum Antosianin dari Kulit Rambutan

Pada gambar 5 terlihat bahwa semakin meningkat temperatur maka absorbansi juga meningkat. Tetapi pada suhu $30{ }^{0} \mathrm{C}$ diperoleh data yang fluktuatif dimana absorbansi pada suhu $30{ }^{0} \mathrm{C}$ pada waku 2 jam memiliki absorbansi 0,9515, pada waktu 4 jam mengalami penurunan absorbansi menjadi 0,8999, pada waktu 6 jam dan 8 jam mengalami peningkatan dengan masing-masing nilai absorbansi adalah 1,3823 dan 2,0693. Pada waktu 2 jam dan 4 jam terjadi data yang fluktuatif. Hal ini dikarenakan terjadi pemanasan yang tidak stabil. Pada suhu yang cukup tinggi antosianin mulai dapat larut dengan baik [2].

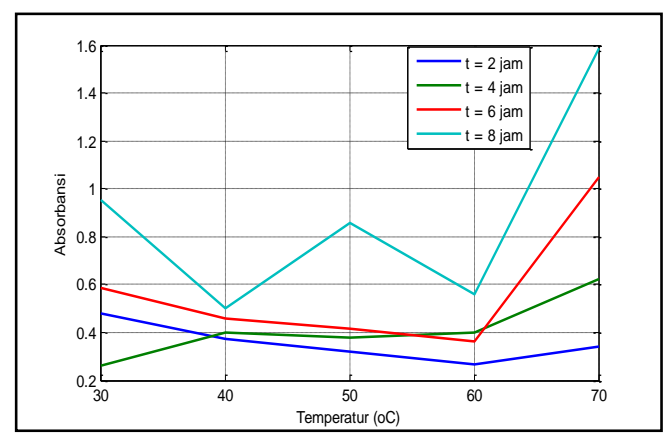

Gambar 6. Pengaruh Waktu Ekstraksi terhadap Absorbansi Maksimum
Pada gambar 6 terlihat bahwa semakin meningkat waktu maka absorbansi juga meningkat. Tetapi pada suhu $30{ }^{0} \mathrm{C}$ diperoleh data yang bersifat fluktuatif dimana absorbansi pada suhu $30{ }^{0} \mathrm{C}$ pada waku 2 jam memiliki absorbansi 0,9515, pada waktu 4 jam mengalami penurunan absorbansi menjadi 0,8999, pada waktu 6 jam dan 8 jam mengalami peningkatan dengan masing-masing nilai absorbansi adalah 1,3823 dan 2,0693. Dari data dapat disimpulkan semakin lama waktu ekstraksi, maka kontak antar zat terlarut dengan pelarut semakin lama sehingga banyak zat terlarut yang akan terambil [14].

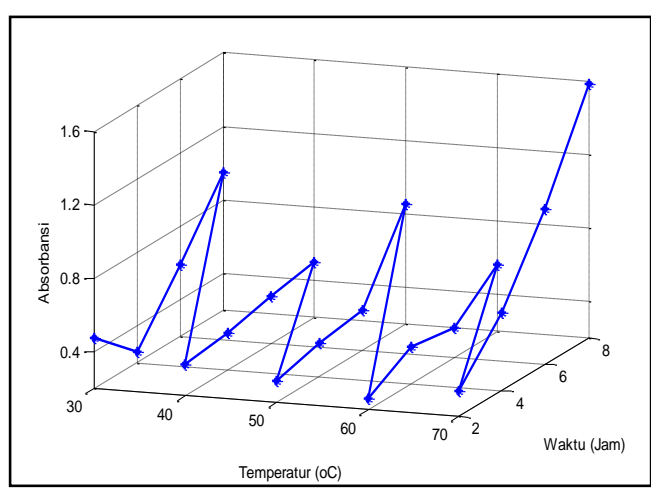

Gambar 7. Pengaruh Temperatur dan Waktu Ekstraksi terhadap Absorbansi Maksimum Antosianin dari Kulit Rambutan

Pada gambar 7 terlihat bahwa intensitas warna tertinggi terjadi pada temperatur $70{ }^{\circ} \mathrm{C}$ dengan waktu 8 jam dan menghasilkan warna hasil ekstrak merah pekat dengan absorbansi 2,6119. Pengaruh temperatur dan waktu terhadap absorbansi antosianin dapat terlihat pada persamaan (1):

$\mathrm{A}=2,2597-0,0143 \mathrm{~T}-0,06793 \mathrm{~T}^{2}+0,0154 \mathrm{t}$ $-0,0008 \mathrm{t}^{2}$...

dengan $\mathrm{A}=$ Absorbansi maksimal, $\mathrm{T}=$ Temperatur $\left({ }^{0} \mathrm{C}\right), \mathrm{t}=$ Waktu $(\mathrm{Jam})$. Persamaan (1) memiliki faktor korelasi 0,7027

\section{Konsentrasi Antosianin}

Konsentrasi antosianin dilakukan dengan metode perbedaan $\mathrm{pH}$ ( $\mathrm{pH}$ Differential) yaitu $\mathrm{pH} \mathrm{1,0} \mathrm{dan} \mathrm{pH} 4,5$ [9].

Pada gambar 8 dapat dilihat bahwa data yang diperoleh bersifat fluktuatif pada suhu 30 ${ }^{0} \mathrm{C}$ dengan waktu 2 jam memiliki konsentrasi 36,4574 $\mathrm{mg} / \mathrm{L}$, kemudian mengalami penurunan pada waktu 4 jam dengan konsentrasi $19,7715 \mathrm{mg} / \mathrm{L}$ dan mengalami peningkatan pada waktu 6 jam dan 8 jam 
dengan masing-masing konsentrasi 44,5768 $\mathrm{mg} / \mathrm{L}$ dan 72,2174 mg/L. Hal ini disebabkan karena pemanasan yang tidak stabil. Semakin tinggi suhu ekstraksi maka kecepatan perpindahan massa dari solute ke solven akan semakin tinggi karena suhu mempengaruhi nilai koefisien transfer massa dari suatu komponen. Temperatur yang lebih tinggi (viskositas pelarut lebih rendah, kelarutan solute lebih besar) pada umumnya menguntungkan unjuk kerja ekstraksi [8].

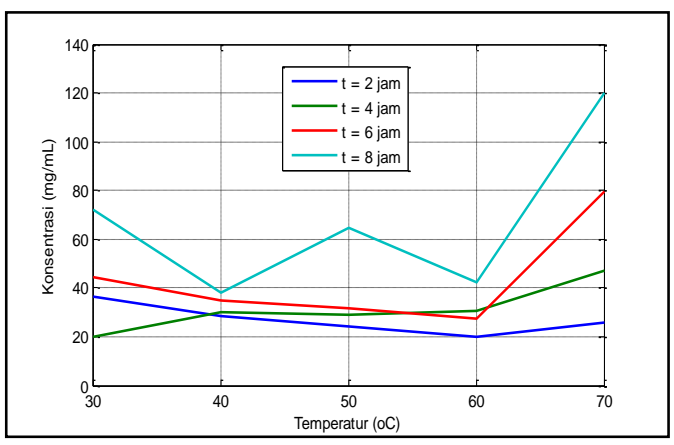

Gambar 8. Pengaruh Temperatur Ekstraksi terhadap Konsentrasi Antosianin dari Kulit Rambutan

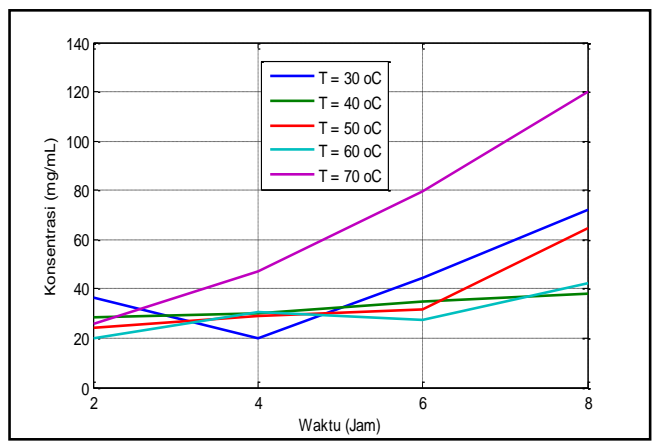

\section{Gambar 9. Pengaruh Waktu Ekstraksi terhadap Konsentrasi Antosianin dari Kulit Rambutan}

Pada gambar 9 terlihat bahwa data fluktuatif pada suhu $30{ }^{\circ} \mathrm{C}$ dengan waktu 2 jam memiliki konsentrasi 36,4574 mg/L, kemudian mengalami penurunan pada waktu 4 jam dengan konsentrasi 19,7715 $\mathrm{mg} / \mathrm{L}$ dan mengalami peningkatan pada waktu 6 jam dan 8 jam dengan masing-masing konsentrasi 44,5768 mg/L dan 72,2174 mg/L. Semakin lama waktu ekstraksi maka semakin banyak antosianin terekstrak [17].

Pada gambar 10 terlihat pengaruh temperatur dan waktu terhadap konsentrasi antosianin dapat diwakilkan dengan menggunakan persamaan kubik ganda. Persamaan model matematiknya dapat ditunjukkan pada persamaan (2):

$\mathrm{C}=734,874-50,641 \mathrm{~T}+1,204 \mathrm{~T}^{2}-0,009 \mathrm{~T}^{3}-$ $21,726 \mathrm{t}+5,000 \mathrm{t}^{2}-0,323 \mathrm{t}^{3}$.

dengan $\mathrm{C}=$ Konsentrasi antosianin, $\mathrm{T}=$ Temperatur, dan $\mathrm{t}=$ Waktu reaksi. Persamaan (2) memiliki faktor korelasi 0,714. Maka dari hasil penelitian dapat disimpulkan bahwa kondisi optimum untuk ekstraksi antosianin dari kulit rambutan dengan menggunakan pelarut etanol yang diasamkan dengan $\mathrm{HCl}$ $0,1 \%$ adalah pada temperatur $70{ }^{\circ} \mathrm{C}$ dengan waktu ekstraksi selama 8 jam yaitu dengan konsentrasi antosianin sebesar 120,1601 mg/L.

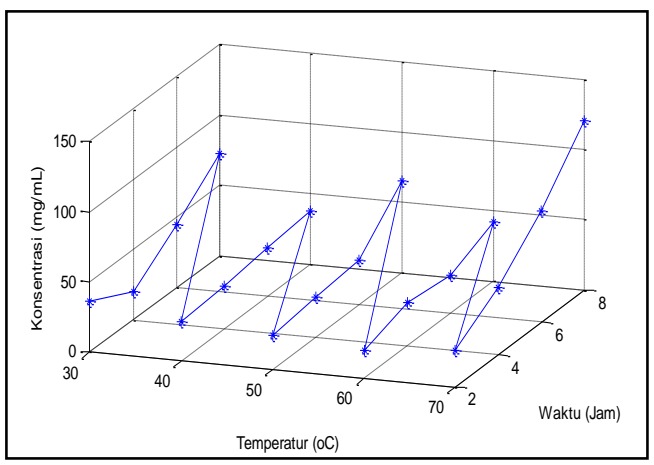

Gambar 10. Pengaruh Temperatur dan Waktu Ekstraksi terhadap Konsentrasi Antosianin dari Kulit Rambutan

\section{Rendemen Antosianin}

Rendemen antosianin menunjukkan persen perolehan antosianin dari kulit rambutan.

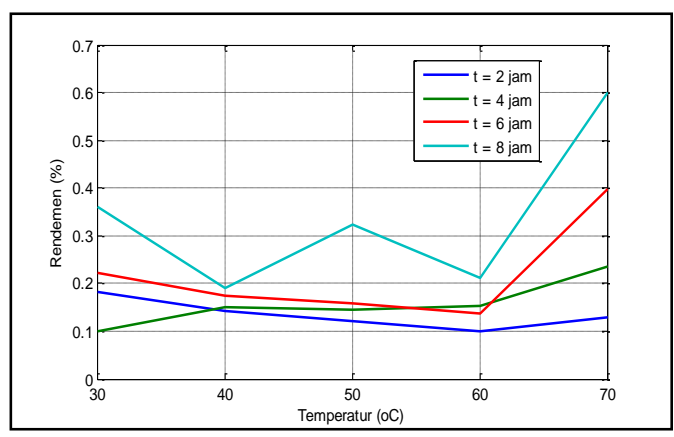

\section{Gambar 11. Pengaruh Temperatur Ekstraksi terhadap Rendemen Antosianin dari Kulit Rambutan}

Pada gambar 11 terlihat bahwa meningkatnya suhu maka perolehan rendemen juga tinggi. Tetapi pada suhu $30{ }^{0} \mathrm{C}$ terjadi perolehan rendemen yang fluktuatif, ini terjadi 
karena temperatur pemanasan yang tidak stabil. Kemudian akan meningkat kembali pada suhu $40{ }^{0} \mathrm{C}$ hingga perolehan rendemen tertinggi pada suhu $70{ }^{0} \mathrm{C}$ dengan perolehan rendemen antosianin adalah 0,6008. Dengan semakin meningkatnya suhu ekstraksi maka terlarutnya pigmen antosianin semakin baik. Bantuan energi berupa panas akan membantu proses pemecahan dinding sel sehingga flavonoid intra sel dapat terekstraksi [7].

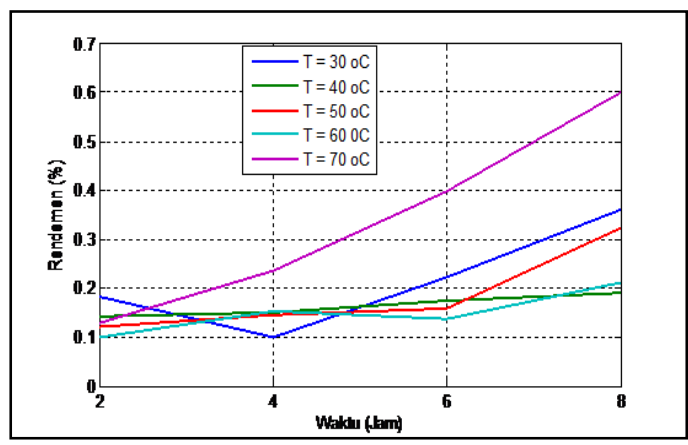

Gambar 12. Pengaruh Waktu Ekstraksi terhadap Rendemen Antosianin dari Kulit Rambutan

Pada gambar 12 terlihat bahwa data nilai rendemen sebanding dengan lamanya waktu ekstraksi dan nilai tertinggi terletak pada waktu 8 jam dengan perolehan rendemennya $0,6008 \%$. Semakin lama waktu ekstraksi maka semakin banyak antosianin terekstrak [18].

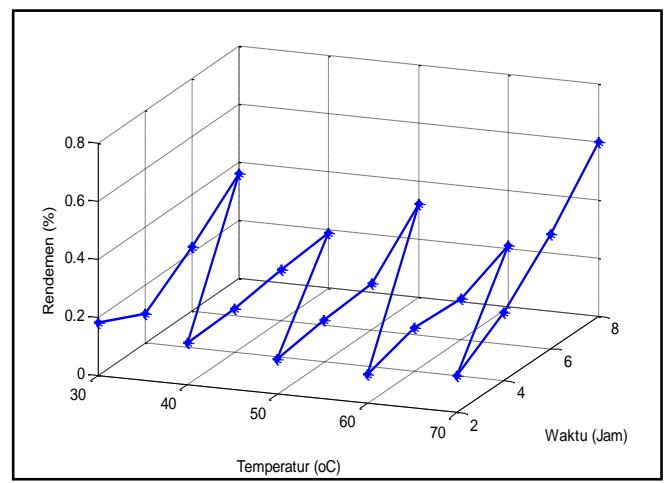

Gambar 13. Pengaruh Temperatur dan Waktu Ekstraksi terhadap Rendemen Antosianin dari Kulit Rambutan

Pada gambar 13 terlihat bahwa data rendemen meningkat dengan kenaikan temperatur dan waktu. Tetapi pada suhu $30{ }^{\circ} \mathrm{C}$ dan $60{ }^{0} \mathrm{C}$ diperoleh data yang fluktuatif. Meningkatnya temperatur maka rendemen ekstrak yang dihasilkan lebih besar karena kelarutan semakin meningkat dan mobilitas partikel meningkat sehingga interaksi antara pelarut dengan zat yang akan diekstrak lebih mudah dan sering terjadi, dimungkinkan jika waktu ekstraksi lebih lama maka rendemen yang dihasilkan lebih besar, karena terpenuhinya waktu kontak antara pelarut untuk berinteraksi dengan zat yang akan diekstrak [13]. Kenaikan waktu proses yang digunakan menghasilkan kenaikan rendemen yang dihasilkan. Lamanya waktu akan mempermudah penetrasi pelarut ke dalam bahan baku [17]. Terdapat penyimpangan pada penelitian diatas, hal ini dikarenakan suhu pemanasan yang tidak konstan. Berdasarkan gambar 13 diperoleh persamaan nonlinear secara kubik yaitu:

$\mathrm{R}=-0,9823+0,0324 \mathrm{t}-0,00562 \mathrm{t}^{2}+0,0007 \mathrm{t}^{3}$ $+0,0324 \mathrm{t}-0,0019 \mathrm{t}^{2}+0,0000143 \mathrm{t}^{3}$.

dengan $\mathrm{R}=$ Rendemen, $\mathrm{t}=$ Waktu dan $\mathrm{T}=$ Temperatur. Persamaan (3) memiliki faktor korelasi 0,7296.

Maka dapat disimpulkan bahwa rendemen antosianin tertinggi terdapat pada ekstraksi pada temperatur $70^{\circ} \mathrm{C}$ dan waktu reaksi selama 8 jam, yaitu sebesar $0,6008 \%$. Hal ini berarti temperatur $70{ }^{\circ} \mathrm{C}$ dan waktu reaksi selama 8 jam merupakan kondisi yang optimum dalam perolehan rendemen antosianin dari kulit rambutan.

\section{Kesimpulan}

Berdasarkan hasil penelitian dapat disimpulkan bahwa kulit rambutan yang diblender menghasilkan nilai absorbansi yang tertinggi yaitu 1,0086 dengan perolehan rendemen sebesar $0,1544 \%$. Kondisi optimum untuk ekstraksi antosianin dari kulit rambutan dengan menggunakan pelarut etanol yang diasamkan dengan $\mathrm{HCl} 1 \%$ adalah pada temperatur $70{ }^{\circ} \mathrm{C}$ dan waktu reaksi selama 8 jam, dengan nilai absorbansi maksimumnya sebesar 2,6119, konsentrasi antosianin sebesar $120,6001 \mathrm{mg} / \mathrm{L}$ dan rendemen antosianin sebesar $0,6008 \%$.

\section{Daftar Pustaka}

[1] Anem, M, Rambutan, Agronomist Gersik Muar Johor: Malaysia, 2013. www.rambutan.blogspot.com/anem.

[2] Asep Muhammad Samsudin, Khoiruddin, "Ekstraksi, Filtrasi Membran dan Uji Stabilitas Zat Warna dari Kulit Manggis (Garcinia mangostana)”, Skripsi, Jurusan Teknik Kimia, Fakultas Teknik, Universitas Diponegoro: Semarang, 2008. 
[3] Aulina Mutiarawati, Ria Prewiti, Muhammad Setyawan, Penetapan Kadar Pigmen Antosianin Daun Jati (Tectona grandis L.f) sebagai Bahan Pewarna Alami Makanan dengan Spektrofotometri $U V$-Vis. PKM Penelitian. Universitas Setia Budi, Surakarta, 2013, hal. 87.

[4] Bondre, Suhma, "Study on Isolation and Purification of Anthocyanins and Its Application As $\mathrm{pH}$ Indicator". International Journal of Advanced Biotechnology and Research. 2012 : hal 699-700.

[5] Elfi Anis Saati, "Identifikasi dan Uji Kualitas Pigmen Kulit Buah Naga Merah (Hylocareus costaricensis) pada Beberapa Umur Simpan dengan Perbedaan Jenis Pelarut", Skripsi, Fakultas Pertanian, Universitas Muhammadiyah Malang: Malang, 2002, hal: 1 .

[6] Endang Kwartiningsih, et, all., "Zat Warna Alami Tekstil dari Kulit Buah Manggis", EkuilibriumVol. 8. No.1, Jurusan Teknik Kimia, Fakultas Teknik UNS, 2009.

[7] Farah Umar, "Optimisasi Ekstraksi Flavonoid Total Daun Jati Belanda", Skripsi, Fakultas Matematika dan Ilmu Pengetahuan Alam Institut Pertanian Bogor: Bogor, 2008.

[8] Geankoplis C.J., "Transport Processess and Unit Operations", Second Edition, Allyn and Bacon, Inc, Toronto, 1991.

[9] Hayati E.K, Budi U.S, Hermawan R, Konsentrasi Total Senyawa Antosianin Ekstrak Kelopak Bunga Rosella (Hibiscus sabdariffa L.) : Pengaruh Temperatur dan $\mathrm{pH}$, Jurnal Kimia Volume 6 No.2, Jurusan Kimia UIN Maulana Malik Ibrahim: Malang, Juli 2012 : 138-147.

[10] Lydia Melawaty "Ekstraksi Pigmen Antosianin Paprika Merah (Capsium anuum) dengan Menggunakan Asam Tartarat”, Skripsi, Jurusan Teknik Kimia UKI: Makassar, 2012.

[11] Lydia Wijaya S., Simon B. Widjanarko, dan Tri Susanto, "Ekstraksi dan Karakterisasi Pigmen dari Kulit Buah Rambutan (Nephelium Lappaceum) Var. Binjai”, Jurnal Teknologi Pangan dan Gizi, Volume 2 Nomor 1, Universitas Brawijaya: Malang, 2001.

[12] M. Andhika Akbar, "Optimasi Ekstraksi Spent Bleaching Earth dalam Recovery Minyak Sawit”, Skripsi, Departemen Teknik Kimia, Fakultas Teknik Universitas Indonesia: Jakarta, 2012.
[13] Mein Suzery, Sri Lestari, Bambang, "Penentuan Total Antosianin dari Kelopak Bunga Rosela (hibiscus sabdariffa 1) dengan Metode Maserasi dan Sokshletasi". Jurnal Sains dan Matematika, Jurusan Kimia Fakultas MIPA. Universitas Diponegoro: Semarang, 2010.

[14] Prima Astuti Handayani, Asri Rahmawati, "Pemanfaatan Kulit Buah Naga (Dragon Fruit) sebagai Pewarna Alami Makanan Pengganti Pewarna Sintetis", Jurnal Bahan Alam Terbarukan, Vol. 1 No. 2, Program Studi Teknik Kimia, Universitas Negeri Semarang: Semarang, 2012.

[15] Rene Nursaerah Mulki Lazuardi, "Mempelajari Ekstraksi Pigmen Antosianin dari Kulit Manggis (Garcinia mangostana L) dengan Berbagai Jenis Pelarut", Tugas Akhir, Jurusan Teknologi Pangan, Fakultas Teknik, Universitas Pasundan: Bandung, 2010.

[16] Rosdiana Moeksin, Stevanus Ronald HP, "Pengaruh Kondisi, Perlakuan dan Berat Sampel Terhadap Ekstraksi Antosianin dari Kelopak Bunga Rosela dengan Pelarut Aquadest dan Etanol'.Jurnal Teknik Kimia, No. 4, Vol. 16, Universitas Sriwijaya, 2009, hal. 17.

[17] Ryan Moulana, Juanda, Syarifah, Ria Rosika, "Efektivitas Penggunaan Jenis Pelarut dan Asam Dalam Proses Ekstraksi Pigmen Antosianin Kelopak Bunga Rosella (hibiscus sabdariffa 1)". Jurnal Teknologi Hasil Pertanian Indonesia, Vol (4) No.3, Fakultas Pertanian, Universitas Syiah Kuala: Banda Aceh, 2012.

[18] Siti Marwati, “Kajian Penggunaan Ekstrak Kubis Ungu (Brassica oleracea L) sebagai Indikator Alami Titrasi Asam Basa”, Seminar Nasional Kimia, Fakultas Matematika dan Ilmu Pengetahuan Alam, Universitas Negeri Yogyakarta: Yogyakarta, 2010. 